\title{
ガスタービン動翼材の疲労特性におよぼす耐食コーティングの影響*
}

\author{
香 川裕 之茥, 根岸睦*2
}

\section{Effect of Corrosion-Resistant Coatings on Fatigue Properties of Gas Turbine Blade Materials}

\author{
Hiroyuki KAGAWA*3 and Atsushi NEGISHI \\ ${ }^{* 3}$ Research and Development Department, The Kansai Electric Power Co., Inc., \\ 3-11-20 Nakoji, Amagasaki-shi, Hyogo, 661-0974 Japan
}

\begin{abstract}
Isothermal low-cycle fatigue tests and thermal-mechanical fatigue tests with linear out-of phase cycles were carried out using cylindrical specimens made of $\mathrm{Ni}$-base superalloy and coated with several kinds of corrosion-resistant coatings. In some tests, fatigue loading was interrupted several times and coating cracks were observed by means of replica technique. As a result, three types of coating cracks were observed, namely, multiple parallel long cracks, multiple parallel short cracks and non-parallel cracks. Multiple parallel long cracks are caused from lack of ductility of coating materials. This type of coating cracks initiate in an early stage of fatigue loading and has a strong effect to reduce fatigue life. Multiple parallel short cracks are caused by fatigue of coating layer. These cracks propagate into the substrate before cracks initiate in the substrate and reduce fatigue life of the coated specimen. Non-parallel coating cracks are caused by propagation of cracks initiated in the substrate and have little effect to reduce fatigue life.
\end{abstract}

Key Words: Coating Material, Heat-Resistant Material, Low-Cycle Fatigue, Thermal-Mechanical Fatigue, Crack Density, Crack Length, Gas Turbine, Blade

\section{1. 粕 言}

発電用ガスタービンの動翼は内部に複雑な形状の冷 却孔を有しており，この孔に圧縮空気が流れることに より内部冷却される，また外表面では高温の燃焼ガス に接しており，起動停止に伴ってガス温度が変化する ため,動翼各部には複雑に変動する熱灿力が発生する(1). 動翼外表面には耐食コーティングもしくは遮熱コーテ イングを施される場合が多いが，一般にコーティング 材料は脆く, 室温から数百 ${ }^{\circ} \mathrm{C}$ 程度の温度域では破断延 性が非常に低い(2)(3).このため動翼のリ一ディングエッ シ (4)，翼面(5)，プラットフォーム年等で，コーティング を起点とした熱疲労き裂の発生事例が報告されている.

動翼材料からなる試験片の表面に耐食コーティング を施して，一定温度のもとでの低サイクル疲労試験, 温度亡歪が同位相で変動するIn Phase 波形や $180^{\circ}$ 位 相がずれる Out-of-Phase 波形の熱機械疲労試験等を 実施した結果が報告されている(7) (14)、試験結果を大雑 把にまとめると，一部例外はあるものの，比較的低温

* 原稿受付 2008 年 6 月 23 日.

*1 正員, 関西電力 (株) 研究開発室電力技術研究所 (㹈 661-0974 尼崎市若王寺 3-11-20)

*2 関西電力 (株) 火力事業本部火力エンジニアリングセンター (要530-6591 大阪市北区中之島 3-6-32).

E-mail : kagawa.hiroyuki@e4.kepco.co.jp
域で引張負荷を受ける場合にはコーティングが割れの 起点となり寿命が低下する傾向が認められ(2),(7),(9),(12) (14)，高温側で引張負荷を受ける場合には基材部が破壊 起点となりコーティングが波労寿命に悪影響を及ぼさ ない傾向が認められる(2),(9)(12) (14).

定期検査等におうて実機動翼にコーティング割れが 検出された場合，割れがコーティング層にとどまって いれば動翼の健全性に直ちに問題を生じるわけではな いが，基材部まで進展していれば何らかの対処が必要 となる.このためコーティング割れの進展状態を非破 壊的に簡便に推定する手法の開発が望まれるが，実機 検査に適用されるには至っていない.コーティングを 施した試験片の疲労試験においてコーティング割れ寿 命を観察した報告もあるが(2)(10)，デー夕点数が少ない こともあり，コーティング割れ挙動が明確になってい るとは棓い難い.

本研究では，3種類のコーティングを施した試験片 を用いて，試験温度と歪速度を変化させた低サイクル 疲労試験, およびOut-of-Phase 波形の熱疲労試験を実 施し，疲労特性に及ぼすコ一ティングの影響を系統的 に調べた結果を報告する，一部の試験片では，試験中 負荷を何度か中断して試験片表面のレプリカを採取し， コーティング割れ挙動の観察を行ったので, その結果 もあわせて報告する. 


\section{2. 試験方法}

試験条件の一覧を表 1 に示す．試験の大半は， $\mathrm{Ni}$ 基 超合金 IN738LC の通常凝固インゴット HIP 処理材を 基材として実施した. インゴットからめ10(GL20)もし くは $\phi 8(\mathrm{GL} 16)$ の中実丸棒試験片を加工し，一部の試 験片はコーティングを施さずに疲労試験に供し，他は 試験片平行部に $\mathrm{CoNiCrAlY}$ 合金粉末（Co-32\% Ni$21 \% \mathrm{Cr}-8 \% \mathrm{Al}-0.5 \% \mathrm{Y})$ を減圧プラズマ溶射して約 $0.2 \mathrm{~mm}$ 厚さのコーティングを施した. コーティング施 工試験片の一部には,さらに $\mathrm{Al}$ 拡散浸透処理を施した. $\mathrm{Al}$ 浸透層の厚さは約 $0.03 \mathrm{~mm}$ であった. コーティング 施工後、真空中で $1120^{\circ} \mathrm{C} \times 2 \mathrm{hr}, 845 \times 24 \mathrm{hr}$ の熱処理 を行って試験に供した。

以上の 3 種類の試験片を用いて, 室温(RT)での低サ イクル疲労 $(\mathrm{LCF})$ 試験と $800^{\circ} \mathrm{C}$ での LCF 試験，および 試験温度を $200^{\circ} \mathrm{C}$ から $800^{\circ} \mathrm{C}$ 間で変動させた Out-ofPhase 波形の熱機械疲労(TMF)試験を実施した. $800^{\circ} \mathrm{C}$ での LCF 試騟は $0.1 \% /$ 秒および $0.0008 \%$ 秒の 2 種類 の歪速度で害施し, TMF 試験は $0.0008 \%$ 秒の歪速度 で実施した. また TMF 試験では, 10 分から 360 分の 範囲の圧縮歪保持を導入した試験も一部実施した。 ま たコーティング未施工の試験片では，900Cの LCF 試 験， $400-800^{\circ} \mathrm{C}$ および $500-900^{\circ} \mathrm{C}$ の Out-of-Phase 波形 の TMF 試験も実施した。

表 1 の Replica 欄に記号 Lを記した試験条件では,
試験中負荷を何度か中断して試験片表面のレプリカを 採取し, 試験後走査型電子顕微鏡で最終破断の原因と なった主き裂長さの変化を測定した. またDを記した 試験片では，コーティングの割れ密度の変化を測定し た. 割れ密度 $(/ \mathrm{mm})$ は, 視野範囲内の割れ長さの総和 を視野面積で除することにより算出した.

一方向凝固超合金 GTD111DS 製の動翼から凝固方 向が長手方向に一致するよう $\phi 4(\mathrm{GL} 8)$ の中実丸棒試験 片を加工し，平行部に CoCrAlY および CoNiCrAlY コ 一ティングを施した後 $\mathrm{Al}$ 拡散浸透処理を施した試験 片を用い, Out-of-Phase 波形の TMF 試験を実施した. この試験では, 全ての試験片でレプリカ観察を実施し 割狆密度を測定した.

\section{3. 試験結果}

3・1 疲労試験結果 IN738LC を基材とした室温 および $800^{\circ} \mathrm{C}$ LCF 試験， $200-800^{\circ} \mathrm{C}$ の TMF 試験の うち圧縮保持のないデータをまとめて図 1 に示す. 疲 労寿命は，試験片が破断したときの繰り返し数，また は最大応力が定常時の3/4 に低下したときの繰り返し 数で定義した.

室温の LCF 試験では, コーティング施工により疲労 寿命が明確に低下し, 寿命低下度合いは CoNiCrAlY コーティングより CoNiCrAlY+Alコーティングの方が 顕著であった， $800^{\circ} \mathrm{C}, 0.1 \%$ 秒の LCF 試験では，寿 命の順番は室温での LCF 試験と同じであったが, コー

Table 1 Experimental conditions

\begin{tabular}{|c|c|c|c|c|c|c|c|c|}
\hline Substrate & Coating & Test Piece & $\begin{array}{l}\mathrm{LCF} / \\
\mathrm{TMF}\end{array}$ & $\begin{array}{l}\text { Temp. } \\
\left({ }^{\circ} \mathrm{C}\right)\end{array}$ & \begin{tabular}{|c|} 
Strain Rate \\
$(\% / \mathrm{sec})$
\end{tabular} & $\begin{array}{c}\text { Strain Range } \\
(\%)\end{array}$ & $\begin{array}{c}\text { Holding Time } \\
\text { (min) }\end{array}$ & Replica \\
\hline \multirow{20}{*}{ IN738LC } & \multirow{10}{*}{ Uncoated } & \multirow{15}{*}{$\phi 10 \times \mathrm{GL} 20$} & LCF & RT & \multirow{2}{*}{0.1} & $1.3,1.0,0.8$ & & \\
\hline & & & LCF & \multirow{2}{*}{800} & & $1.0,0.8,0.6$ & & L \\
\hline & & & LCF & & 0.0008 & $1.3,1.0$ & & \\
\hline & & & LCF & \multirow{2}{*}{900} & \multirow{2}{*}{0.1} & 0.6 & & $\mathrm{~L}$ \\
\hline & & & LCF & & & 0.6 & 30 & $\mathrm{~L}$ \\
\hline & & & TMF & & \multirow{3}{*}{0.0008} & $1.3,1.0,0.75$ & & \\
\hline & & & TMF & $200-800$ & & 1.0 & $10,60,360$ & \\
\hline & & & TMF & $400-800$ & & 0.6 & & $\mathrm{~L}$ \\
\hline & & & TMF & $500-000$ & 0.001 & 0.6 & & $\mathrm{~L}$ \\
\hline & & & TMF & $500-900$ & 0.003 & 0.6 & & $\mathrm{~L}$ \\
\hline & \multirow{5}{*}{ CoNiCrAlY } & & LCF & $\mathrm{RT}$ & \multirow{2}{*}{0.1} & $1.3,1.0,0.8$ & & \\
\hline & & & LCF & \multirow{2}{*}{800} & & $1.0,0.8,0.6$ & & \\
\hline & & & LCF & & \multirow{3}{*}{0.0008} & $1.3,1.0$ & & \\
\hline & & & TMF & \multirow{2}{*}{$200-800$} & & $1.3,1.0,0.75$ & & \\
\hline & & & TMF & & & 1.0 & 60 & \\
\hline & \multirow{5}{*}{$\mathrm{CoNiCrAlY}+\mathrm{Al}$} & \multirow{5}{*}{$\phi 8 \times$ GL16 } & LCF & $\mathrm{RT}$ & \multirow{2}{*}{0.1} & $1.3,1.0,0.8$ & & \\
\hline & & & LCF & \multirow{2}{*}{800} & & $1.0,0.6$ & & $\mathrm{~L}, \mathrm{D}$ \\
\hline & & & LCF & & \multirow{3}{*}{0.0008} & $1.3,1.0$ & & $\mathrm{~L}, \mathrm{D}$ \\
\hline & & & TMF & $200-800$ & & $1.3,1.0,0.75$ & & $\mathrm{~L}, \mathrm{D}$ \\
\hline & & & TMF & & & 1.0 & 10,60 & $\mathrm{~L}, \mathrm{D}$ \\
\hline \multirow{2}{*}{ GTD111DS } & $\mathrm{CoCrAlY}+\mathrm{Al}$ & \multirow{2}{*}{$\phi 4 \times \mathrm{GL} 8$} & TMF & \multirow{2}{*}{$400-900$} & \multirow{2}{*}{0.0017} & $1.2,0.7$ & & $\mathrm{D}$ \\
\hline & $\mathrm{CoNiCrAlY}+\mathrm{Al}$ & & TMF & & & $1.2,0.7$ & & D \\
\hline
\end{tabular}

L : Crack length, D : Crack density 


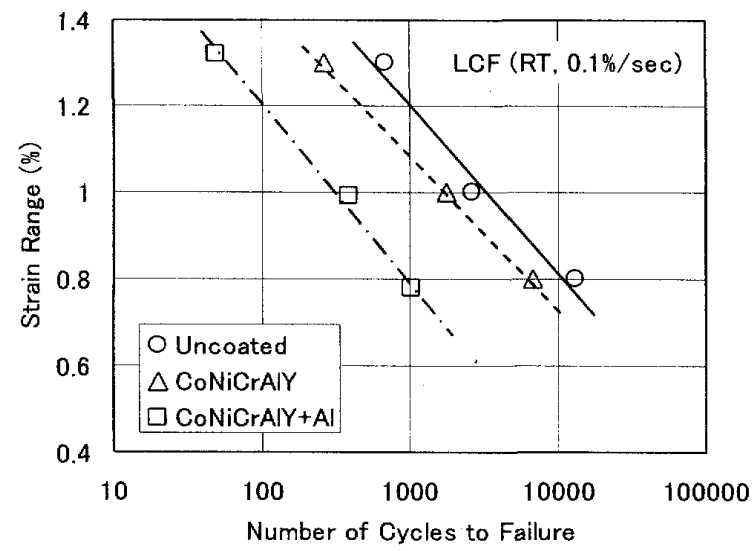

(a) LCF test results at $\mathrm{RT}(0.1 \% / \mathrm{sec})$

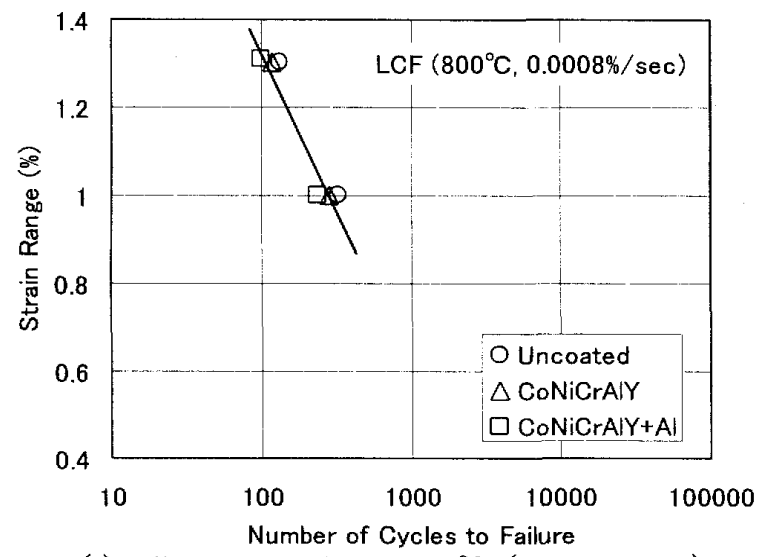

(c) LCF test results at $800^{\circ} \mathrm{C}(0.0008 \% / \mathrm{sec})$

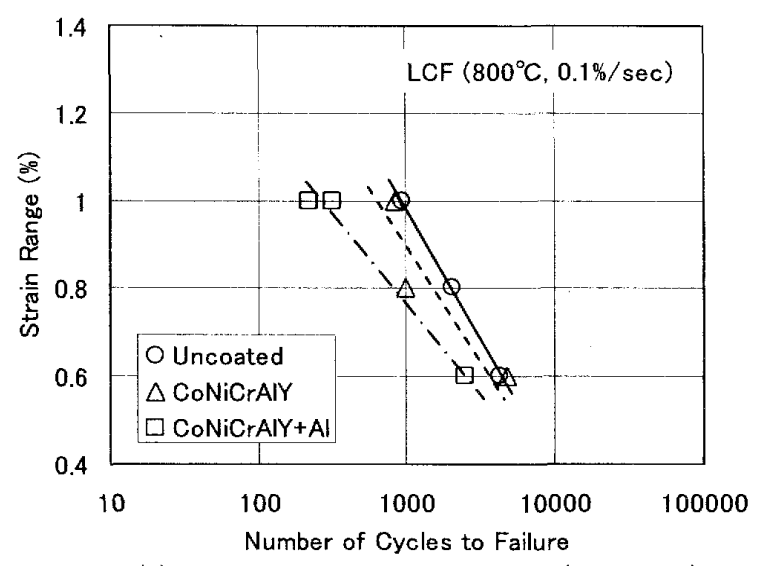

(b) LCF test results at $800^{\circ} \mathrm{C}(0.1 \% / \mathrm{sec})$

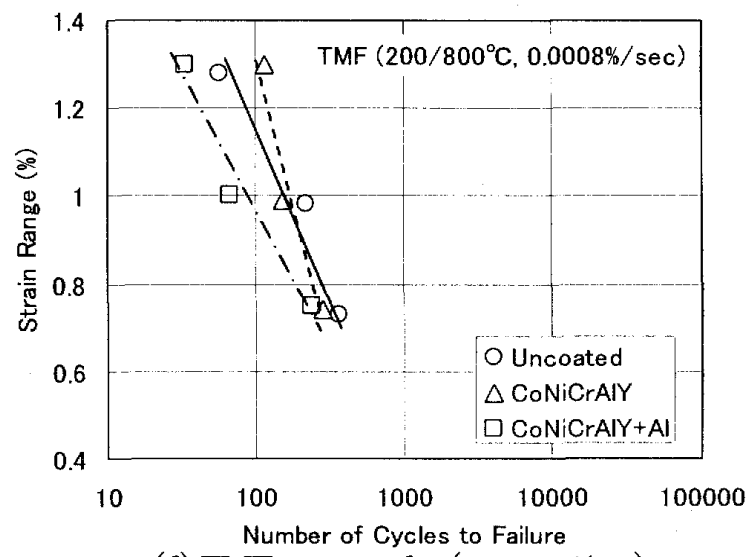

(d) TMF test results $(0.0008 \% / \mathrm{sec})$

Fig.1 Fatigue test results (IN738LC)

ティングによる寿命低下の度合いは室温 LCF 試験よ り小さかつた。一方 $800^{\circ} \mathrm{C}, 0.0008 \% /$ 秒の LCF 試験 では，コーティングによる寿命低下は認められなかっ た. TMF 試験では, CoNiCrAlY コーティング材の寿 命はコーティング施工のない試験片とほぼ同等であっ たが，CoNiCrAlY+Al コーティング材では寿命が若干 低下する傾向を示した。疲労寿命に及ぼすコーティン グの影響については 4 節で詳しく検討する.

つぎに疲労負荷条件別に寿命を比較すると，コーテ イング施工がない場合には, 室温の LCF, $800^{\circ} \mathrm{C}$ LCF $(0.1 \% /$ 秒 $), 800^{\circ} \mathrm{C}$ LCF $(0.0008 \% /$ 秒 $), \mathrm{TMF} の$ 順に長寿命であった. IN738LC コーティング末施工材 の Out-of-Phase 波形の TMF 寿命之高温 LCF 寿命と の比較については，前者の方が長寿命である結果(13)や ほぼ同等との結果(15)などが報告されているが，本試験 では後者の方が若干長寿命となる結果となった. CoNiCrAlY コーティング材の寿命もコーティング未 施工材と同じ順番であった。一方 $\mathrm{CoNiCrAlY}+\mathrm{Al}$ コ一 ティング材では, TMF 寿命が最も短寿命であったが,
他の 3 条件の寿命はほぼ同等であった。

圧縮保持を有する TMF 試験結果を，寿命と保持時 間の関係で図 2 に示す。歪範囲はいずれも $1 \%$ あ゙ある. 圧縮保持がない場合にはコーティングの有無や種類に より TMF 寿命に差異を生じたが, 压縮保持がある場

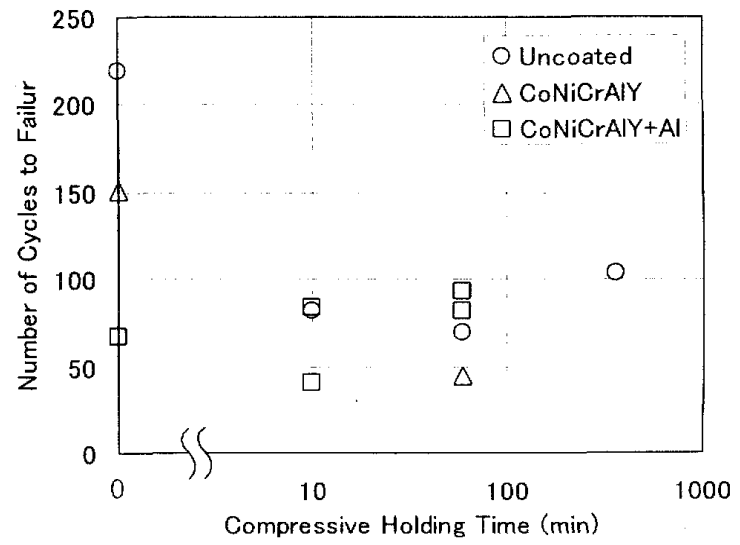

Fig.2 Effect of compressive holding on TMF life (strain range is 1.0\%) 
合には寿命がコーティングの有無や種類にあまり影響 されず，CoNiCrAlY+Al コーティング材の保持なしの 場合の寿命と同等程度であった.

コーティング未施工試験片の $\mathrm{LCF}\left(800^{\circ} \mathrm{C}, 0.0008 \%\right.$ l 秒)試験と TMF 試験（圧縮保持試験を含む）の歪範囲 $1 \%$ での応力変化の様子を図 3 に示す. TMF 試験では 引張の平均応力が生じていること, 平均応力の值が圧 縮保持の有無にあまり影響されていないことが分かる. TMF 試験における歪振幅と, 寿命の半分程度の繰り返 し数における引張最大応力および圧縮最大応力との関 係を，図 4 に示す. 白抜きプロットは圧縮保持のない

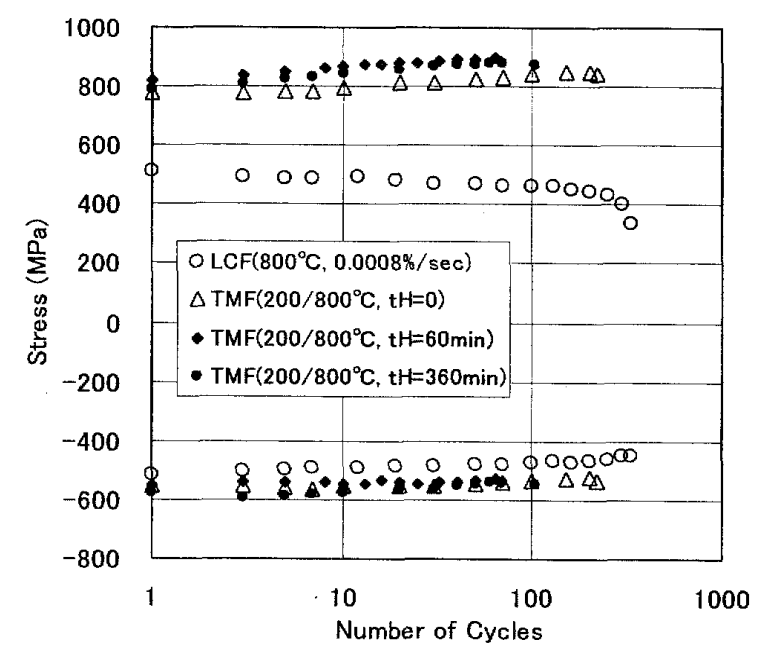

Fig.3 Relation between tensile and compressive maximum stress and number of cycles for uncoated specimens (strain range: 1\%)

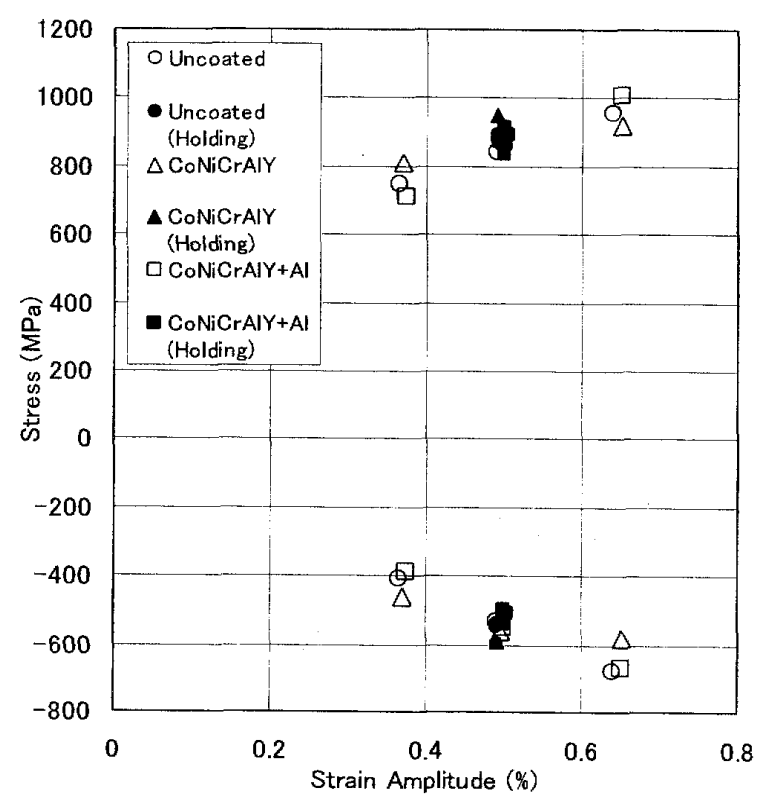

Fig.4 Relation between tensile and compressive maximum stress and strain amplitude for TMF tests
場合の，黒塗りプロットは圧縮保持がある場合の結果 であり，コーティングの有無にかかわらず全データを まとめて表示してある. 平均応力が压縮保持に影響さ れていないことが分かる. IN738LC 800Cにおいて 歪速度 $0.0001 \%$ 秒で引張負荷した後応力緩和試験を 実施した結果（緩和開始応力：約 500MPa）, 約 2000 秒経過してもほとんど応力緩和しなかった結果が報告 されている(16). 若干条件が異なるが，本試験でも圧縮 保持中に応力緩和が生じず，このため平均応力に圧縮 保持が影響を及ぼさなかったと考えられる.

IN738LC コーティング未施工試験片の TMF 寿命が $\mathrm{LCF}\left(800^{\circ} \mathrm{C}, 0.0008 \%\right.$ 秒) 寿命より短寿命であった原因 の1つとして, 平均応力の影響が推測される. 压縮保 持を有する $\mathrm{TMF}$ 試験の場合, 平均応力は保持なしの 場合と変わらなかったが，寿命は保持なしの場合より 短寿命であった．この原因は明確ではないが，歪保持 時の酸化の影響なざが推測される。

GTD111DS の TMF 試験における歪範囲 1.2\%での 寿命は, CoNiCrAlY+Al コーティング材で 913 回,

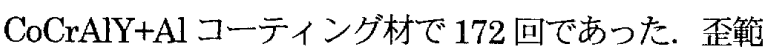
囲 $0.7 \%$ の試験では, 前者で 1000 回, 後者で 100 回程 度負荷した後，未破断のまま試験を中止した.

\section{3·2 コーティング割れのレプリカ観察 IN738LC} に CoNiCrAlY+Alコーティングを施工した試験片を用 いて $800^{\circ} \mathrm{C} て ゙$ 実施した 4 本の LCF 試験において,コ一 ティング割れ密度の変化を測定した結果を図 5(a)に示 す.横軸は, 繰り返し数 $N$ を寿命 $N_{f}$ で除した值である. また同じ試験片を用いた 5 本の TMF 試験（圧縮保持 条件も含む) の同様の結果を, 図 5(b)に示す。

$800^{\circ} \mathrm{C}$ LCF $\left(0.0008 \%\right.$ /秒) では, $N / N_{f}=0.2 \sim 0.4$ 程度でコーティング割れが発生し始め, 繰り返し数が 増すにしたがって割れ密度が次第に増加する傾向が認 められる. またこの場合の破断時の割れ密度は, $1 / \mathrm{mm}$ 程度であった. $800^{\circ} \mathrm{C} の \mathrm{LCF}(0.1 \% /$ 秒 $)$ では, 試験 の初期段階でのデータがないため明確ではないが， 0.0008\%秒の場合より早い段階でコーティング割机が 発生し，かつ割机密度もより高い傾向が認められる。

TMF 試験では, 寿命の $1 \%$ 程度のごく初期段階でコ 一ティング割れが発生し，寿命の $10 \%$ 程度までには割 れ密度が $8 / \mathrm{mm}$ 程度に達し，その後寿命に到達するま でほぼ一定值を保つ傾向が認められた．この傾向は歪 範囲の大小や圧縮保持の有無にかかわらず，5本の試 験片でおおむね同じであった。

レプリカによりコーティング割れを観察した例を， スケッチで図 6 に示す.いずれも基材は IN738LCで 


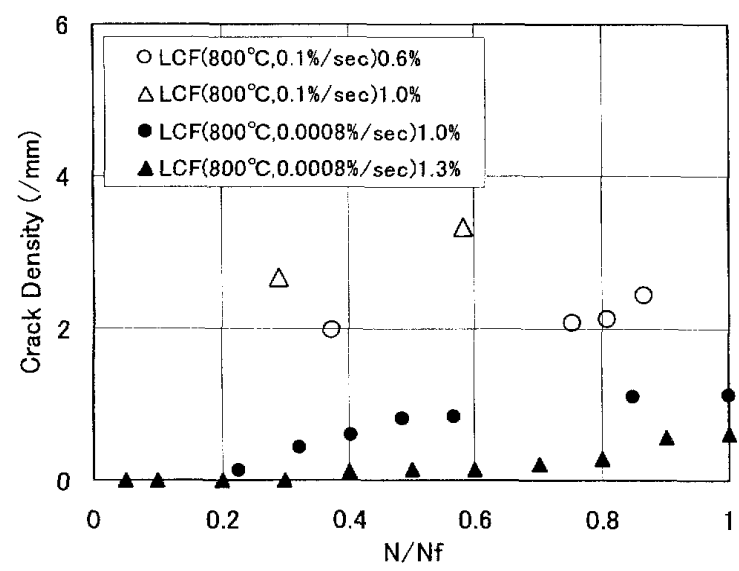

(a) LCF tests at $800{ }^{\circ} \mathrm{C}$

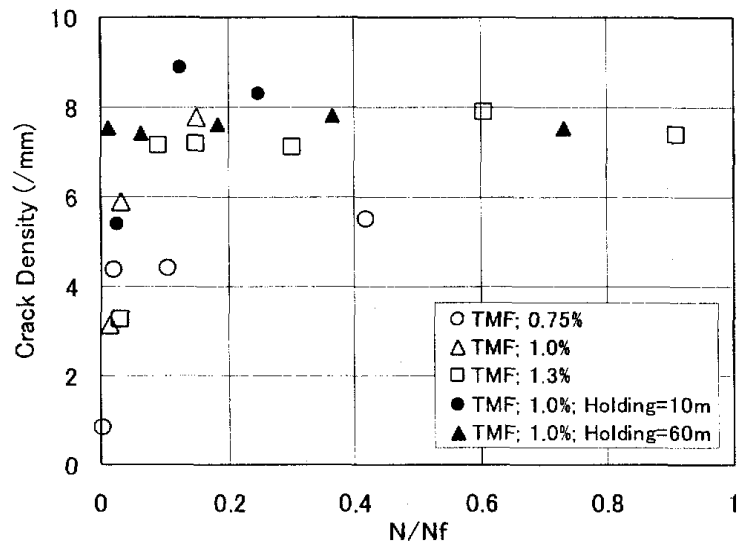

(b) TMF tests

Fig.5 Change of coating crack density on specimen surface (IN738LC, CoNiCrAlY+Al coating)

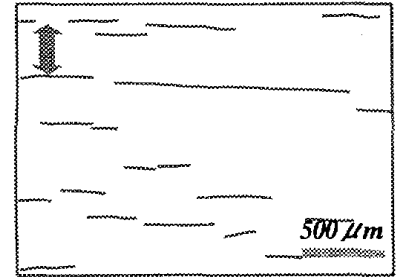

(a) $\mathrm{CoNiCrAlY}+\mathrm{Al}$ $\mathrm{LCF}\left(800^{\circ} \mathrm{C}, 0.1 \% / \mathrm{sec}\right)$ $\Delta \varepsilon=0.65 \%, N / N_{\digamma} 0.38$

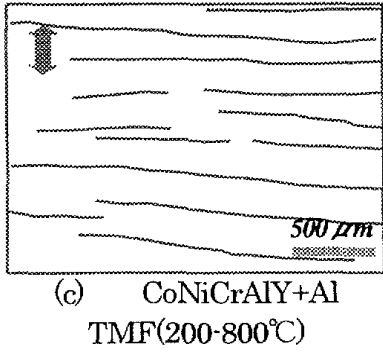

$\Delta \varepsilon=0.75 \%, N / N_{F}=0.42$

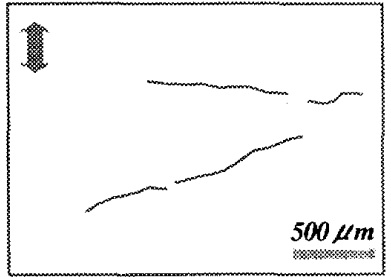

(b) $\mathrm{CoNiCrAlY}+\mathrm{Al}$ $\mathrm{LCF}\left(800^{\circ} \mathrm{C}, 0.0008 \% / \mathrm{sec}\right)$ $\Delta \varepsilon=1.0 \% . N / N=0.41$

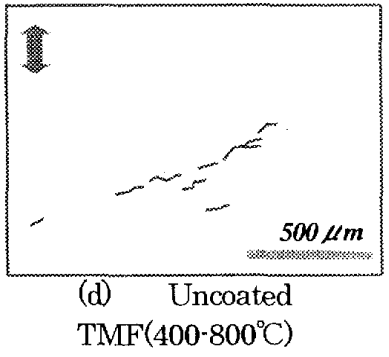

$\Delta \varepsilon=0.6 \%, N / N_{F}=0.41$
Fig.6 Examples of replica observation (IN738LC). An arrow in each figure shows loading direction.
ある. (a)〜(c)は CoNiCrAlY+Al コーティング施工試験 片，(d)は未施工試験片であり，いずれも $N / N_{F}=0.4$ 程度 での観察結果である. CoNiCrAlY+Al コーティング施 工試験片の割れの様子を比較すると, $800^{\circ} \mathrm{C}$ LCF $(0.1 \% /$ 秒)では直線状の平行な割れが多数観察される が，それぞれの割れはあまり連続しておらず比較的短 い割れが多い. $800^{\circ} \mathrm{COLCF}(0.0008 \% /$ 秒) では割れ は直線状でなく，また荷重方向（紙面上下方向）に直 交しているとも限らない. TMF 試験では直線状の平行 な割れが多数観察され，またそれぞれの割れ長さが長 く連続している傾向が認められる. 一力コーティング 未施工試験片の TMF 試験では, 荷重方向に直交して いない短い割劢が多数発生しており, IN738LC 材のミ クロ組織の影響を受けていることが推測される.

GTD111DS に CoCrAlY+Al および CoNiCrAlY+Al コーティングを施工した試験片を用いた TMF 試験に おいて，コーティング割れ密度の変化を測定した結果 を図 7 に示す．横軸は繰り返し回数である.4 本の試 験片とも，10回程度の繰り返し数で割れ密度が飽和す る傾向を示した，飽和後の割れ密度は，CoCrAlY+Al コーティング材を歪範囲 $1.2 \%$ で負荷した場合に 1 ～ $/ \mathrm{mm}$ 程度であったのに対し, 他の 3 条件では 6 ～8/mm 程度であった。

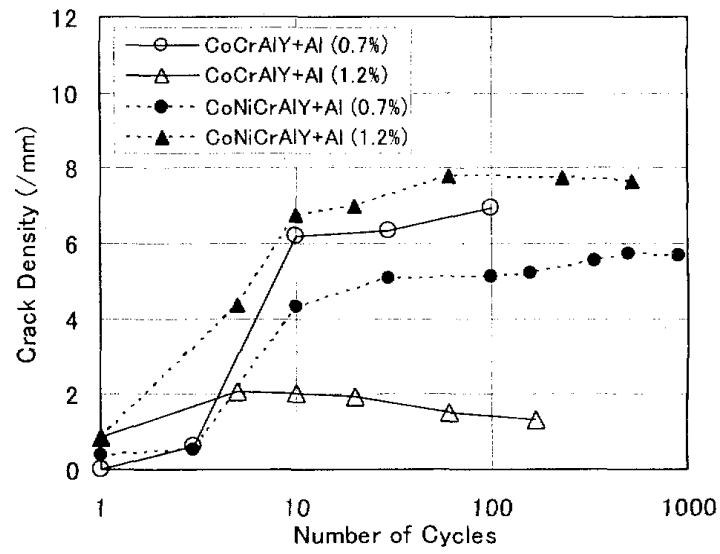

Fig.7 Change of coating crack density on specimen surface (GTD111DS, CoCrAlY+Al coating and CoNiCrAlY+Al coating)

3 •3 き裂長さの観察結果ＩN738LC コーティン

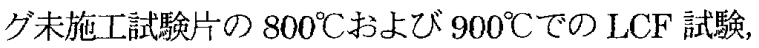

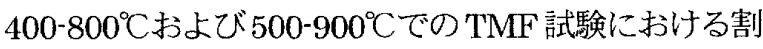
れ長さと $N / N_{f}$ の関係を図 8 に示す，図には最終破断の 原因となった主き裂だけでなく，観察した全ての視野 でのき裂長さをプロットしてある，き裂長さは $N / N_{f}$ $=0.1$ で $0.1 \mathrm{~mm}$ 程度, $N / N_{f}=1$ で $10 \mathrm{~mm}$ 弱であった. 


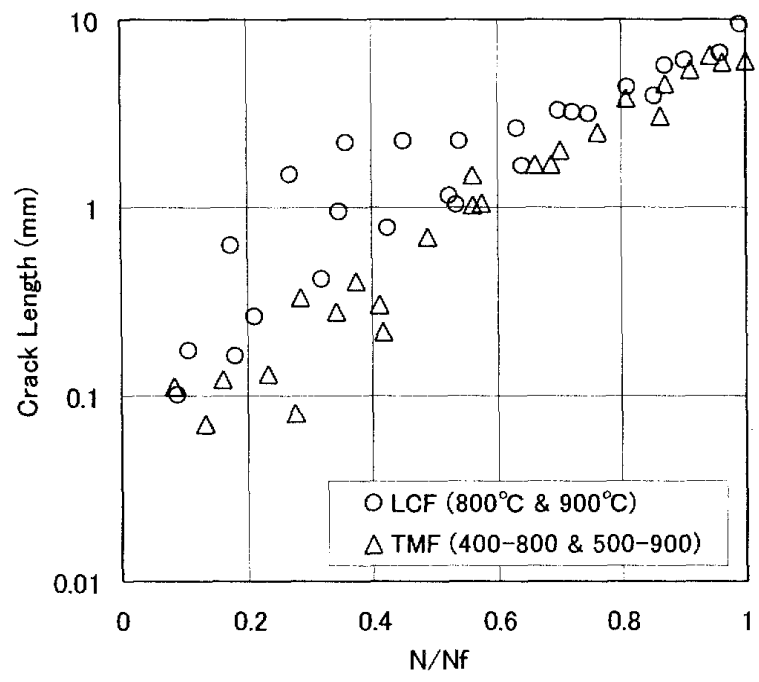

Fig.8 Change of crack length on specimen surface (IN738LC, Uncoated)

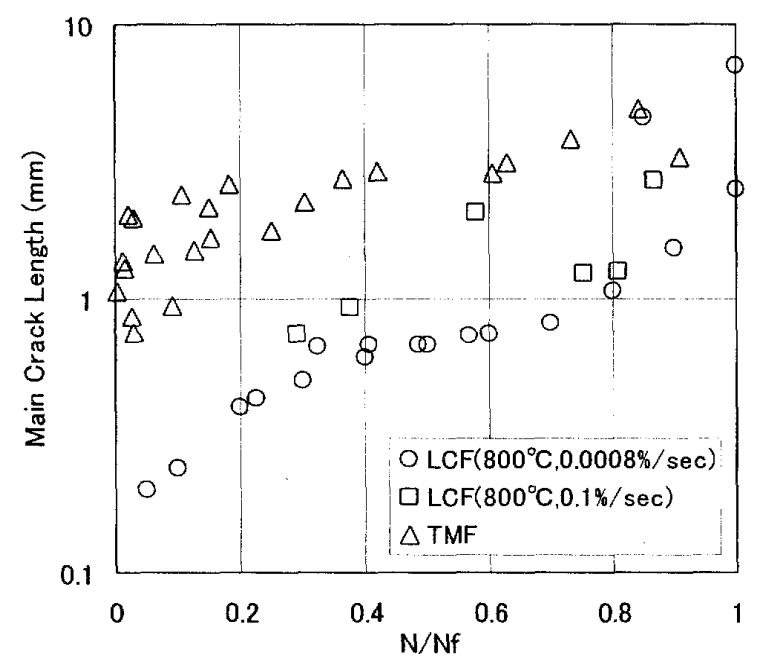

Fig.9 Change of main crack length on specimen surface (IN738LC, CoNiCrAlY+Al coating)

IN738LC に CoNiCrAlY+Al コーティングを施工し た試験片の $800^{\circ} \mathrm{C}$ LCF $(0.0008 \% /$ 秒 $), 800^{\circ} \mathrm{C}$ LCF $(0.1 \% /$ 秒) およびTMF 試験における主き裂長さの観 察結果を困 9 に示す。図 9 には主き裂長さだけがプロ ットされている. $800^{\circ} \mathrm{C} の \mathrm{LCF}(0.0008 \% /$ 秒) 試験で は $N / N_{f}=0.1$ での主さ裂長さが $0.3 \mathrm{~mm}$ 程度であるのに 対し, TMF 試験では $N / N_{f}=0.1$ ですでに $1 \sim 2 \mathrm{~mm}$ で あった. $800^{\circ} \mathrm{C}$ LCF $(0.1 \% /$ 秒) 試験における主き 裂長さは, 両者の中間程度であった.

\section{$3 \cdot 4$ コーティング割れの断面観察ＧTD111DSに} $\mathrm{CoCrAlY}+\mathrm{Al}$ およびCoNiCrAlY+Al コーティングを施 工した試験片を用いた $\Delta \varepsilon=1.2 \%$ の $\mathrm{TMF}$ 試験の破 断後の試験片の断面観察結果を図 10 に示す. 後者では $\mathrm{Al}$ 拡散浸透層に多数の割执が発生し，そのうちの一部
がコーティング層を貫通して基材部まで進展していた. 一方前者では, 割れの数は少ないが割れは全てコーテ イング層を貫通して基材部まで進展しており，また図 では分からないが試験片全周に亘る割れとなっていた。

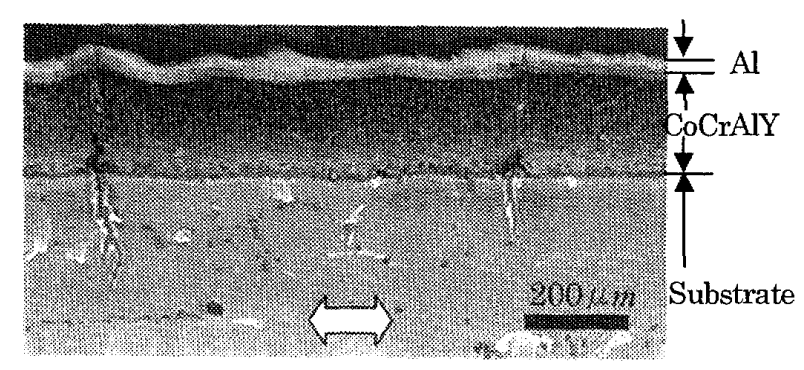

(a) $\operatorname{CoCrAlY}+\mathrm{Al} \quad(\Delta \varepsilon=1.2 \%, N=172)$

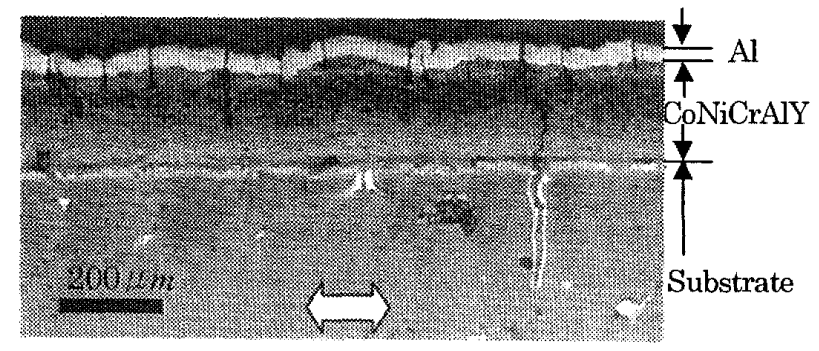

(b) $\mathrm{CoNiCrAlY}+\mathrm{Al}(\Delta \varepsilon=1.2 \%, \mathrm{~N}=913)$

Fig.10 Coating cracks in GTD111DS specimens. An arrow in each figure shows loading direction.

\section{4. 考察}

4・1 疲労毒命に及ほすコーティングの影慗 IN738 LC の LCF 寿命に及ぼす CoCrAlY コーティングの影 響についてはこれまで多くの報告がなされており (7)(12)(14)，400〜 450 Cで引張を受ける負荷形態の場合に はコ一ティングにより寿命が低下し, $800^{\circ} \mathrm{C}$ 以上で引張 を受ける場合には影響を受けないかあるいはむしろ寿 命が向上している. また CoNiCrAlY+Al コーティング の場合, $400^{\circ} \mathrm{C}$ で引張を受ける負荷形態の場合にはコ一

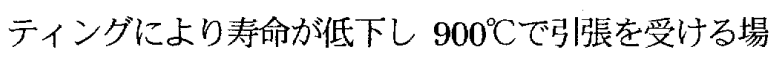
合にはコーティングにより寿命が向上すること(13),

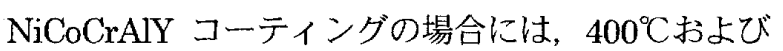
$850^{\circ} \mathrm{C}$ LCF 試験でコーティングによる影響がないこ と(9), が報告されている. 以上のように比較的低温域で 引張を受ける場合にコーティングにより寿命が低下す る原因としては，コーティングの破断延性を上回る引 張が負荷されることによるコーティング割れが挙げら

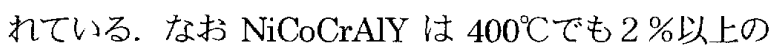
高い破断延性を示すため(3)，400Cでの LCF 試験でも 寿命に悪影響を及ぼさなかったものと考えられる.

本報の試験のうち IN738LCに CoNiCrAlY+Al コー 
ティングを施した試験データでは, $200^{\circ} \mathrm{C}$ 以下で引張を 受ける負荷形態ではコーティングによる寿命低下を示 しており，従来の報告と同様コーティング割れで説明 することができる. LCF(RT)試験ではコーティング割 れのレプリカ観察を実施していないが, TMF 試験と同 様寿命のごく初期段階で割れを生じているものと推測 される. 図 1 で比較すると TMF 試験の方が LCF(RT) 試験より短寿命であるが，この差はき裂進展速度の差 に起因するものと考えられる. $800^{\circ} \mathrm{C}$ のCF 試験では 負荷速度によってコーティングが疲労寿命に及ぼす影 響が異なっている. コーティングの割れ形態や割れ密 度も異なる傾向を示しており，これらの影響について は次節以降で検討する。

CoNiCrAlY コーティングの場合, 室温ではコーティ ングによる寿命低下が認められたが，低下の度合いは CoNiCrAlY+Al コーティングに比べると小さかった. また 200-800 Cの TMF 圾験においては, CoNiCrAlY $+\mathrm{Al}$ コーティングの場合と異なり, コーティングによ る明確な寿命低下が認められなかった. コーティング の破断延性はAl含有量が高い方が低い傾向にあり(2)(7),

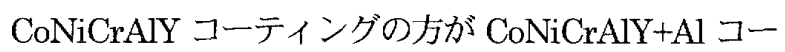
ティングの Al 拡散浸透層より割れにくかったためと 考えられる.このことは, CoNiCrAlY+Al コーティン グの TMF 試験（図 10(b)）に拈いて, Al 拡散浸透層の 割れの多くが CoNiCrAIY 層との界面に留まっている ことからも裏付けられる.

\section{$4 \cdot 2$ コーティング割れ挙動 本試験において}

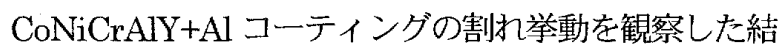
果, 図 6(a)〜(c)に示すように, 大きく分けて 3 種類の 割れ形態が認められた.すなわち TMF 試験で見られ る荷重方向に直交する[平行な長い割れ」， $800^{\circ} \mathrm{C} の$ LCF $(0.1 \% /$ 秒) 試験で見られる「平行な短い割れ」, および $800^{\circ} \mathrm{C}$ ○CF $(0.0008 \%$ 秒) 試験で見られる「平 行でない割れ」の3 種類である. 平行な長い割れの場 合, 図 5(b)から分かるように, 疲労負荷のごく初期段 階で高い割れ密度に達し，その後ほぼ一定の割れ密度 を保っていた. 平行でない割れの場合は破断寿命の 20 〜 40\%程度の繰り返し数で割れが発生し，その後次第 に割れ密度を増していくが，破断時の彗れ密度は長い 平行割れの場合の $1 / 10$ 程度であった，平行な短い割れ の場合，割れ密度は平行な長い割れと平行でない割れ の中間の値であった.

平行な長い割れは, 4.1 節で検討したように, 破断延 性を上回る引張負荷によるコーティング割れと考えら れる.このような割れは疲労負荷のごく初期段階に発
生し，寿命を大幅に低下させる，CoCrAlY および $\mathrm{CoNiCrAlY}$ コーティングともに, Al 拡散浸透処理を 施した試験片は, 歪範囲 $0.7 \%$ での TMF 試験 (400-900ㄷ) においてコーティング割れを生じており (図 7), $\mathrm{Al}$ 拡散層は $400^{\circ} \mathrm{C}$ に拈いて引張歪 $0.35 \%$ て割 れを生じるものと考えられる. 図 $10(\mathrm{a})$ では $\mathrm{Al}$ 拡散層 に生じた割れが全て CoCrAlY 層まで貫通している. 図 には示していないが歪範井 $0.7 \%$ では Al 拡散層に発生 した割れて殆どが CoCrAlY 層との界面で留まってお

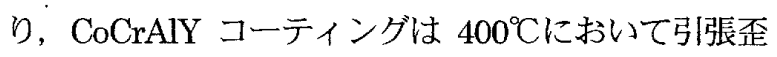
0.35\%では割れを生じないが $0.6 \%$ では割れると推定さ れる. CoCrAlY コーティング単体の引張試験における 割れ歪が $400^{\circ} \mathrm{C} て ゙ ~ 1 \%$ 弱であることが報告されている が(12), TMF 試験では高温側圧縮負荷での応力緩和によ り平均応力が引張側へ移動することや(12)，コーティン グ施工時にコーティング層に引張残留応力が発生する こと(17)を考虑に入れると，この報告結果は本推定結果 と矛盾しない。

図 10(b)では $\mathrm{Al}$ 拡散層に生じた割れの多くが CoNiCrAlY 層との界面で留まっており, CoNiCrAlY

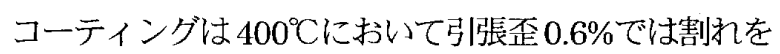
生じないと考えられる. CoCrAlY+Al コーティングで は $1.2 \%$ TMF 試験により $\mathrm{Al}$ 拡散層ばかりでなく CoCrAlY 屏にも割扎を生じたため (図 10(a)), 割れ深 さが梁く割れ問隔が広くなったものと推測される。一 方 CoNiCrAlY+Al コーティングでは $1.2 \%$ TMF 試 験では Al 拡散層だけが割れ (図 10(b)), 割れ深さが浅 く割れ間隔が狭くなったものと考えられる゙。

コーティング割れのうち平行でない割れを発生する $800^{\circ} \mathrm{C}$ LCF (0.0008\%/秒) 試験では、コーティング の有無が疲労寿命に影響を及ぼしていない（図1)。ま たこのときの主き裂長さ (図 $9 \bigcirc$ プロット) がコーテ

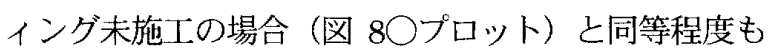
しくはむしろ若干短いことから，図 6(d)に示すような 基材部の割れがコーティングに伝播して生じたものと 推測される.

平行な短い割れを生じる $800^{\circ} \mathrm{C}$ LCF ( $0.1 \%$ 秒) 試験では，コーティングにより寿命が明確に低下して

† コーティングの割れ深さを $a$ 、割れ間隔を $h$ とする。コ一ティ ングの割れ歪をと,とするとき，弾性変形を仮定すると，コーティ ング割れの応力拡大係数は $K \cong E \varepsilon, \sqrt{\pi a}$ ，このときの割れ開口 変位は $\delta=8\left(1-v^{2}\right)(K / E) \sqrt{a /(2 \pi)} \cong 4 \sqrt{2}\left(1-v^{2}\right) a \varepsilon_{f}$ となる. 割 れによりコーティング表面の歪が完全に開放されると仮定すると, $h \varepsilon_{f}=\delta$, 従つて $h \cong 4 \sqrt{2}\left(1-v^{2}\right) a$ となり, 割れ墚さと割机間 隔は㧍执双比例することになる.なお $E$ とレはコーティング のヤング率とポアソン比である. 
おり，したがって破壊起点は基材部ではなくコーティ ング部と考えられる。しかしながら割れ密度（図 5) や主き裂長さ (図 9) は, 平行な長い割れを生じる TMF 試験の場合とは明らかに異なる傾向を示している.こ れらのことから，平行な短い割れはコーティングの疲 労き裂であり，基材部にき裂が発生する前にコ一ティ ングき裂が基材部に進展したため，コーティング末施 工試験片より短寿命になったものと推測される.

$\mathrm{NiCoCrAlY}$ コーティング単体の歪速度 $0.1 \%$ 秒での LCF 試験結果が報告されており(18)，歪範囲 $1 \%$ での寿 命をグラフから読み取ると試験温度 $650^{\circ} \mathrm{C}$ で約 900 回,

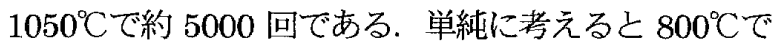
の寿命はこの中間に位置すると推測され，図 1 (b)から 読み取ったIN738LC 単体の $1 \%$ での寿命(約 1000 回) 之同等以上と考えられる. しかしながら CoNiCrAlY +Al コーティングの破断延性は NiCoCrAlY コーティ ングより低いためLCF 寿命もより短いと推測されこ のため CoNiCrAlY+Al コーティング試験片では基材部 (IN738LC)にき裂が生じる前に $\mathrm{Al}$ 拡散層に疲労き裂 (平行な短い割れ)が発生したと考えても矛盾はない.

\section{4 •3 き裂長さと疲労寿命の関係 $\mathrm{CoNiCrAlY}+\mathrm{Al}$} コーティング試験片の TMF 試験では, 負荷開始直後 に1〜2 $\mathrm{mm}$ のコーティング割れ発生が観察された(図 9).コーティング未施工試験片の場合, 図 8 より, き 裂長さが 1 2 $\mathrm{mm}$ に達するまでに寿命の約半分が費 やされることが分かる. 図 1(d)より CoNiCrAlY+Al コーティング試験片の寿命は未施工試験片の寿命の約 半分になっており，この違いはコーティング割れによ り定量的に解釈することができる.

CoNiCrAlY+Al コーティング材の TMF 試験では, 圧縮保持の有無にかかわらず負荷開始值後にコーティ ング割れが生じている(図 5(b)).また最大応力が注縮 保持の有無に影響されないことから（図 3，図4）き裂 進展速度も影響されないと考えれば，寿命が圧縮保持 により殆ど影響されなかった結果（図 2）も不思議で はない.

$800^{\circ} \mathrm{C}$ のCF (0.1\%/秒)試験の場合でも, CoNiCrAlY $+\mathrm{Al}$ コーティングにより寿命が半分程度に低下してい る. しかしながらき裂長さと $N / N_{f}$ の関係で見ると, コ

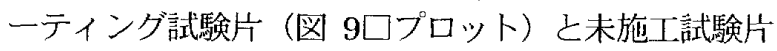

（図 8○プロット）に有意な差は認められない。

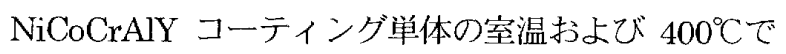
の疲労き裂進展速度が IN738LC の速度と比較され， いずれの温度でも前者の方が進展速度が明膫に速いこ とが報告されている(19)、CoNiCrAlY のき裂進展データ
は見出せなかったが, NiCoCrAlY と大差がないと仮定 すれば，また，コーティング試験片の寿命の大半がコ 一ティング部でのき裂発生・進展に占められていると 仮定できれば, コーティングの有無による寿命の差は, コーティングと基材とのき裂進展速度の差に起因する と推測できるかもしれない.

\section{$4 \cdot 4$ 実機動翼のコーティング割れ $\mathrm{CoNiCrAlY}$} +Al コーティングを施した実機動翼に割れが検出され た場合，図 6(b)のような平行でない割れであれば基材 部にもき裂が発生していると考光られるが，(a)や(c)の ような平行な割れの場合にはき裂が基材部まで達して いるかどうかはコーティング割れの観察だけでは分か らない，ただ図 7 のプロットのようにコーティング 割れの間隔が広い場合には，図 10(a)に示される上うに 割れの先端が $\mathrm{Al}$ 拡散層を超えてコーティング層に進 展している可能性が高く, 注意を要する.

実機動翼では Out-of-Phase 波形に近い波形の熱疲 労を受けるが，この波形による TMF 試験の場合，寿 命の数\%もしくはそれ以下の非常に早い段階でコーテ イング割れを生じる．実機ガスタービンでは定期点検 等で必ず長期停止する場合があり，このとき動翼の温 度は室温まで低下する. したがってコーティング割れ が破断延性を上回る引張負荷により発生するのであれ ば，つまり 1 回もしくは数回程度の繰り返しで発生す るのであれば、コーティング割れの評価は室温に対し て実施すべきであり，この意味で最低温度が $400^{\circ} \mathrm{C}$ 程 度の TMF 試験はコーティングの寿命低減効果を過小 評価している可能性がある.

\section{5. 結 言}

主として IN738LC に 2 種類のコーティングを施し た試験片および未施工試験片を用いて，温度と負荷速 度を変えた 3 種類の低サイクル疲労 (LCF) 試験およ び Out-of-Phase 波形の熱機械疲労（TMF）試験を実 施し，疲労特性に及ぼすコーティングの影響を調べた。 得られた結論は以下の通りである.

(1) $\mathrm{CoNiCrAlY}+\mathrm{Al}$ コーティング試験片では，200 $\mathrm{C}$ 以 下の温度で引張を受ける負荷波形では，コーティング により寿命が顕著に低下した. また CoNiCrAlY コー ティング試験片では, 室温の LCF 試験でコーティング により寿命が低下した．これらの寿命低下は，コーテ イングが破断延性を上回る引張ひずみを受けて負荷初 期段階で割れたことに起因する。

(2) $\mathrm{CoNiCrAlY}+\mathrm{Al}$ コーティング試験片の $800^{\circ} \mathrm{Cにお}$ 
ける LCF 試験 (高温域で引張を受ける負荷波形)では, 歪速度により寿命やコーティング割狆形態が異なった。 $0.1 \% /$ 秒の歪速度の場合には破壊起点はコーティング でありコーティングにより寿命が低下したが, $0.0008 \%$ 秒では破壊起点が基材部之推測され，コーテ イングが寿命に及ぼす影響は認められなかった。

(3) 3 種類のコーティング割れ形態が観察された. すな わち平行な長い割れ，平行な短い割れおよび平行でな い割れである. 平行な長い割れはコーティングが破断 延性を上回る引張ひずみを受けることにより負荷初期 段階に発生するコーティング割れであり，寿命を大幅 に低下させた．平行な短い割れはコーティングの疲労 による割れで, やはり寿命低下効果を示した. 平行で ない割れは基材部に発生したき裂がコーティングに進 展したもので，寿命に影響を及ぼさなかった。

\section{参考文献}

(1) Russell, E.S., Practical Life Prediction Methods for Thermal-Mechanical Fatigue of Gas Turbine Buckets, Proceedings of Conference on Life prediction for High Temperature Gus Turbine Materials, Weiss, V. and Bakker, W.T., eds., EPRI AP-4477, Electric Power Research Institute, Palo, Alta, CA. (1986), pp.(3-1)-(3-39).

(2) Wood, M.I., The Mechanical Properties of Coatings and Coated Systems, Materials Science and Engineering, A121, (1989), pp.633-643.

(3) Take, K., Kaku, M., Okamoto, R., Ohtani, R., Kanazawa, N., Tensile Properties of High-Temperature CorrosionResistant MCrAlY Coating (in Japanese), The Society of Materials Science Japan Annual Meeting, , (1997), pp.205206.

(4) Bernstein, H.L., Allen, J.M., Analysis of Cracked Gas Turbine Blades, Journal of Engineering for Gus Turbines and Power, Vol.114, (1992), pp.293-301.

(5) Morita, A., Kagawa, H., Kubo, S., Evaluation of Multiple Crack Propagation Behavior in Gas Turbine Blade under Thermal Fatigue Condition, Transactions of the Japan Society of Mechanical Engineers, Series A, Vol.72, No.722, (2006), pp.1213-1219.

(6) Kagawa, H., Yoshiba, M., Failure Analysis of HighTemperature Coatings at Gas Turbine Bucket for Power Plants, Current Advances in Materials and Processes, Vol.19. No.3, (2006), p.595.

(7) Bernstein, H.L., Grant, T.S., McClung, R.C. and Allen, J.M., Prediction of Thermal-Mechanical Fatigue Life for Gas Turbine Blades in Electric Power Generation, ASTM STP 1186, American Society for Testing and Materials, Philadelphia, (1993), pp.212-238.

(8) Itoh, Y., Saitoh, M., Ishiwata, Y., Low-Cycle Fatigue Life Properties of MCrAlY Alloy Coated Systems, Quarterly Journal of the Japan Welding Society, Vol.15, No.1, (1997), pp.141-146.
(9) Take, K, Kaku, M., Kanazawa, N., Ohtani, R., High Temperature Low Cycle Fatigue Property of Coated Ni-Base Super Alloy for Gas Turbine, Proc. 34 . Symposium on Strength of Materials at High Temperature, The Society of Materials Science Japan, (1996), pp.99-103.

(10) Sadasue, T., Fujita, A., Okazaki, M., Mutoh, Y., Saitoh, M., Fatigue Strength of Aluminized Ni-Base Superalloys, Proc. $34^{\text {th }}$. Symposium on Strength of Materials at High Temperature, The Society of Materials Science Japan, (1996), pp.104-108.

(11) Sadasue, T., Fujita, A., Okazaki, M., Mutoh, Y, Saitoh, M, High Temperature Strength and Long Term Aging of CoNiCrAlY Coated and Aluminized Ni-Base Superalloy (in Japanese), The Society of Materials Science Japan Annual Meeting, , (1997), pp.203- 204.

(12) Take, K., Ohtani, R., Kaku, M., Takenaka, T., Masuo, H., Low-Cycle and Thermo-Mechanical Fatigue of Coated IN738LC, Proc. $6^{\text {th }}$ Liege Conference on Materials for Advanced Power Engineering, (1998), pp.1569-1578.

(13) Subcommittee on Superalloys and Coatings in JSMS, Technical Report on "Thermo-Mechanical and Isothermal Cycle Fatigue Strength of Ni-Base Superalloys and Protective Coatings" Phase I Activity, ed. Okazaki, M., The Society of Materials Science, Japan, (2000).

(14) Ogata, T., Nomoto, A., Influence of Corrosion Resistance Coating on Thermo-Mechanical Fatigue Life of Gas Turbine Blade Material IN738LC, Journal of the Society of Materials Science, Japan, Vol.52, No.2, (2003), pp.139-145.

(15) Nitta, A., A Study on Thermal-Mechanical Fatigue of Heat-Resistant Metallic Materials for Power Plants, Komae Research Laboratory Report. No.T25, Central Research Institute of Electric Power Industry, (1993).

(16) Yaguchi, M., Yamamoto, M., Ogata, T., Development of High Temperature Strength Evaluation Method for Inconel 738LC ( $4^{\text {th }}$ Report: Extension of Inelastic Constitutive Equations to Anisothermal Condition), Komae Research Laboratory Report. No.T99017, Central Research Institute of Electric Power Industry, (2000).

(17) Itoh, Y., Saitoh, M., Miyazaki, M., Residual Stress Characteristics of High-Temperature Protective MCrAlY Coating, Transaction of the Japan Society of Mechanical Engineers, Series A, Vol.60, No.569, (1994), pp141-146.

(18) Gayda, J., Gabb, T.P., Miner, R.V., Low Cycle Fatigue Behavior of a Plasma-Sprayed Coating Material, International Joumal of Fatigue, Vol.8, No.4, (1986), pp.217-223.

(19) Kanazawa, N., Ohtani, R., Take, K, Kaku, M., Okamoto, R., Crack Propagation Behavior of High-Temperature Corrosion-Resistant MCrAlY Coating (in Japanese), The Society of Materials Science Japan Annual Meeting, , (1997), pp.207- 208. 